\title{
Morphometric Variations of Nile Tilapia (Oreochromis niloticus) (Linnaeus, 1758) (Perciformes, Cichlidae) Collected from Three Rift Valley Lakes in Ethiopia
}

\author{
Berhan Asmamaw $^{1^{*}}$ and Misikire Tessema ${ }^{1}$ \\ ${ }^{1}$ Ethiopian Biodiversity Institute, Animal Biodiversity Directorate, Aquatic Animals Biodiversity Case \\ Team, P. O. Box 30726, Addis Ababa, Ethiopia
}

*Correspondence :

bichiruet@yahoo.co.uk

Received : 2020-04-29

Accepted : 2021-07-24

Keywords :

Morphometric variations, Oreochromis niloticus, Condition factor

\begin{abstract}
The pattern of morphometric differentiation among three populations of Tilapia (Oreochromis niloticus) sited in Koka, Ziway, and Langano lakes in the Ethiopian rift valley was examined. Morphometric differentiation was examined, compared and quantified by the use of twelve different body measurements in 391 specimens to generate baseline information for conservation and product improvement plans. The result revealed that comparisons of mean values of morphometric measurements in the three studied tilapia populations statistically significant differences $(\mathrm{P}<0.05)$. The Fulton's condition factor (K) of Oreochromis niloticus samples collected from Lakes Koka, Ziway, and Langano was 1.48, 1.2, and 0.66, respectively. The Discriminant Function Analysis performed on seven variables led to a correct classification in $90.5 \%$ of cases. Differences observed between samples in this study indicated that there is important morphometric variation between the studied tilapia populations. Plotting the two significant canonical discriminant functions separated the Lake Langano population from the other two.
\end{abstract}

\section{INTRODUCTION}

Tilapia is the second most cultured fish species in the world next to carp (Zhou et al., 2015). It is considered as the ideal fish species for aquaculture mainly due to its rapid growth, high fecundity, ability to resist poor water quality, and good performance under sub-optimal nutritional conditions (Hassanien et al. 2011; Hasan and Tamam, 2019; Hasan et al., 2019).

In Ethiopia, Tilapia is an important commercial fish species, distributed in all the rift valley lakes and some other high land lakes and rivers (Mengesha, 2015; Golubtsov and Mina, 2003). It contributes more than $50 \%$ of the total landings of fish caught per year in Ethiopia (Tesfaye and Wolff, 2014) and is considered the most edible fish species (Janko, 2015). The aquatic genetic resources management considers several activities that should be performed in every water body depending on the fish species and nature of the geographic locations. The identification of threats and morphological and/or molecular characterizations come first when conservation is proposed.

Morphological variation is a necessity for taxonomic identity, population differentiation, and genetic diversity assessment for the effective management of fisheries resources. Its 
existence among populations indicates that there might be genetic or/and nongenetic (environmental) factors and their interactions resulting in a unique population structure in each water body. According to Naeem and Salam (2005), morphometric and meristic studies of animals are part of the vigorous tools for measuring the discreteness of the same species.

Characterization of $O$. niloticus based on morphometric and meristic variables have also been reported elsewhere (Mert and Cicek, 2010; Yakubu and Okunsebor, 2011; Nazrul et al., 2011; Samaradivakara et al., 2012; Hockaday et al., 2000; Espinosa-Lemus et al., 2009; Hassanien et al., 2011; Naeem et al., 2011). Research work on the morphometric characterization of fish in Ethiopia is not very common. This study is therefore planned to quantify and compare the possible morphometric variations between $O$. niloticus populations from three rift valley lakes in Ethiopia. It also aimed to generate baseline information for further product improvement and conservation plans.

\section{METHODOLOGY}

\section{Place and Time}

This research was conducted for a month at the three main rift valley lakes
(Koka, Ziway and Langano) of Ethiopia in 2019/2020. Lake Koka (Latitude $08^{\circ} 24^{\prime} 0^{\prime \prime}$ $\mathrm{N}$, Longitude $39^{\circ} 35^{\prime} \mathrm{O}^{\prime \prime} \mathrm{E}$ ) is formed as a result of damming of the Awash River for hydropower in the late 1960s. The surface area of the lake is $250 \mathrm{~km}^{2}$ with a maximum and mean depth of $14 \mathrm{~m}$ and 9 $\mathrm{m}$, respectively (LFDP, 1997). It is located at an altitude of $1,590 \mathrm{~m}$ above sea level.

The region around Lake Koka has a total average annual rainfall of about 630 $\mathrm{mm}$ and an average surface water temperature of $19{ }^{\circ} \mathrm{C}$ (averaged for the period between 1998 and 2009) (Mesfin, 2009). Lake Ziway is a freshwater lake. It is $31 \mathrm{~km}$ long and $20 \mathrm{~km}$ wide and has a surface area of $440 \mathrm{~km}^{2}$ and a maximum depth of $9 \mathrm{~m}$ (Awulachew et al., 2007). Lake Ziway is situated between $7^{\circ} 51^{\prime}$ to $8^{\circ} 7^{\prime} \mathrm{N}$ and $38^{\circ} 43^{\prime}$ to $38^{\circ} 56^{\prime} \mathrm{E}$ with an altitude of $1636 \mathrm{~m}$ above sea level (Merga et al., 2020). Lake Langano is situated at $037^{\circ} 55.423 \mathrm{~N}, \quad 05^{\circ} 94.541^{\prime} \mathrm{E}$, with an altitude of $1110 \mathrm{~m}$ (Hirut et al., 2019). It has a surface area of $230 \mathrm{~km}^{2}$ and a maximum depth of $46 \mathrm{~m}$. It contains reddish-brown water attributable to the quantity of iron-containing silt compounds (Talling and Talling, 1965; Wood and Talling 1988). The study areas were mapped with ArcGIS and given in Figure 1.

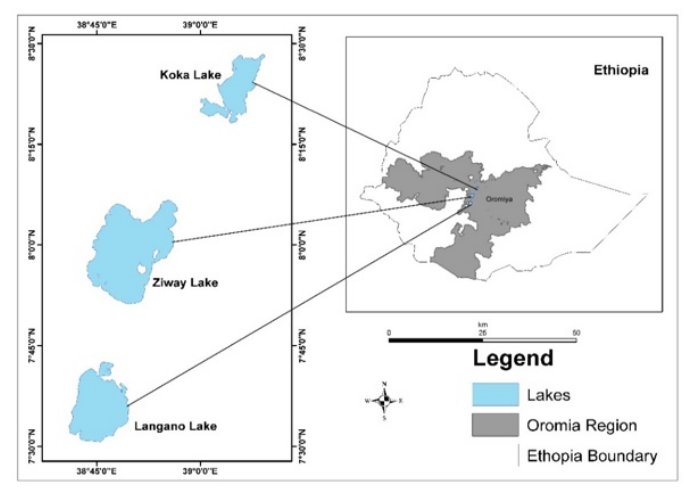

Figure 1. Map of the study.

\section{Research Materials}

The tools used in this research were scale $(\mathrm{cm})$ and digital balance $(\mathrm{g})$. The materials used in this research were 391
O. niloticus fish samples obtained from fishermen at landing sites along the lakes (Ziway, Langano, and Koka). 


\section{Research Design}

This study was conducted by taking 12 different body measurements of tilapia fish samples (O. niloticus) collected from the three main rift valley lakes of Ethiopia.

\section{Work Procedure}

\section{Sample Collections and Measurements of Morphometric Variables}

O. niloticus fish samples were obtained from fishermen at landing sites along the lakes (Ziway, Langano, and Koka). A total of 391 specimens of $O$. niloticus (Figure 2) were obtained and taken to the nearby laboratory of the Batu Fish and Other Aquatic Life Research Centre for morphometric analyses.

A total of 12 morphometric characters were measured using a centimeter scale to the nearest centimeter and body weights were measured using a digital balance to the nearest gram. The morphometric measurements were Total length (TL), Standard Length (SL), Body depth (BD), Pre-orbital length (POL), Prepectoral length (PPCL), Pre-pelvic length (PPLL), Pre-dorsal length (PDL), Pre-anal length (PAL), Caudal height $(\mathrm{CH})$, Head length (HL), Eye Diameter (ED), Bodyweight (W).
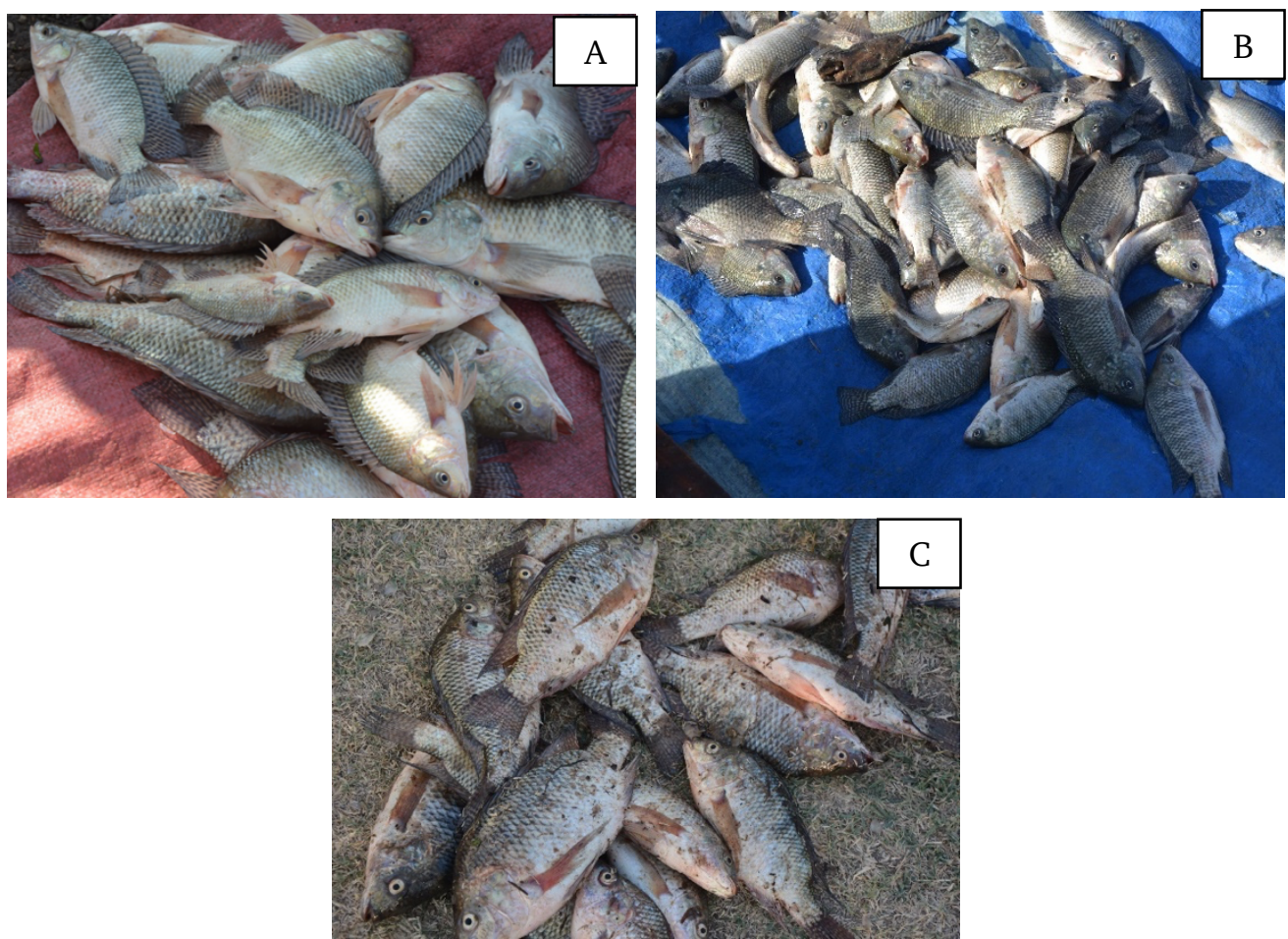

Figure 2. Photos of $O$. niloticus from the study areas $(\mathrm{A}=$ Koka, $\mathrm{B}=$ Langano, $\mathrm{C}=$ Ziway).

\section{Data Analysis}

All statistical analyses were performed using SPSS Version 23 and Microsoft excel. All morphometric measurements were divided by standard length (SL) of each fish to correct sizedependent variation in morphometric characters (Elliott and Hurley, 1995) before conducting any further statistical analysis. The samples were categorized into three groups/populations based on the water body they were caught vis., group I Ziway population ( $\mathrm{N}=130)$, group II Koka population ( $\mathrm{N}=132)$, and group III Langano population $(\mathrm{N}=129)$ for convenience of interpretation.

An equation in the form of $\mathrm{W}=\mathrm{aL}^{\mathrm{b}}$ (which was transformed to the logarithm of the form $\log W=\log a+b \log L$ ), where $\mathrm{W}$ is the bodyweight of fish in grams, $\mathrm{L}$ is the total length in centimeters, ' $a$ ' is the intercept and ' $b$ ' is the slope of the regression line was used to calculate the 
relationship between length (L) and weight (W) of fish (Wootton, 1990) in each population. The relationship between the length ( $\mathrm{L}$ ) and weight (W) of a fish is usually expressed by the equation $\mathrm{W}=\mathrm{aLb}$, where ' $a$ ' is the intercept and ' $b$ ' is the allometry coefficient.

Values of the exponent ' $b$ ' provide information on fish growth. When ' $b$ ' $=3$, increase in weight is isometric. When the value of ' $b$ ' is other than 3 , the weight increase is allometric (positive if ' $b$ ' $>3$, negative if ' $b$ ' $<3$ ). This is a useful tool that provides important information concerning the structure and function of fish populations (Anderson, 1996).

The correlation coefficients between transformed variables and standard length were calculated to check if the data transformation was effective in removing the effect of size in the data. The Fulton Condition factor (K) was also calculated for each population using the formula $\mathrm{K}=\mathrm{W} / \mathrm{L}^{3} \mathrm{x} 100$ (Bagenal and Tesch, 1978): where $\mathrm{K}$ is the condition factor, $\mathrm{W}$ is the bodyweight of fish in grams, and $\mathrm{L}$ is the total length in centimeters. Data obtained were subjected to factor analysis using Discriminant Function Analysis (DFA) and a distribution graph was generated using SPSS Version 23.

\section{RESULTS AND DISCUSSION Morphometric Characters}

The descriptive data of all measured morphometric characters (after divided by standard length) comprising mean values, standard deviations, and coefficient of variation (CV) are presented in Table 1.

Table 1. Descriptive data of O. niloticus sampled from Lakes Ziway, Langano, and Koka.

\begin{tabular}{|c|c|c|c|c|c|c|c|c|c|c|c|c|}
\hline \multirow{2}{*}{$\begin{array}{l}\text { Morpho- } \\
\text { metric } \\
\text { Characters }\end{array}$} & \multicolumn{3}{|c|}{$\begin{array}{l}\text { Koka Reservoir } \\
\quad(\mathrm{N}=132)\end{array}$} & \multicolumn{3}{|c|}{ Lake Ziway $(\mathrm{N}=130)$} & \multicolumn{3}{|c|}{$\begin{array}{l}\text { Lake Langano } \\
\quad(\mathrm{N}=129)\end{array}$} & \multicolumn{3}{|c|}{ All data } \\
\hline & Mean & SD & CV \% & Mean & SD & CV \% & $\begin{array}{c}\text { Mea } \\
\mathrm{n}\end{array}$ & SD & CV \% & $\begin{array}{c}\text { Mea } \\
\mathrm{n}\end{array}$ & SD & CV \% \\
\hline SL $(\mathrm{cm})$ & & & & & & & & & & & & \\
\hline TL $(\mathrm{cm})$ & $\begin{array}{c}1.31 \\
39\end{array}$ & $\begin{array}{c}0.028 \\
84\end{array}$ & 2.19 & $\begin{array}{c}1.32 \\
72\end{array}$ & $\begin{array}{c}0.0586 \\
0\end{array}$ & 4.41 & $\begin{array}{c}1.36 \\
58\end{array}$ & $\begin{array}{c}3.65 \\
0\end{array}$ & 2.67 & $\begin{array}{c}1.33 \\
51\end{array}$ & $\begin{array}{c}0.048 \\
39\end{array}$ & 3.62 \\
\hline PDL (cm) & $\begin{array}{c}0.37 \\
20\end{array}$ & $\begin{array}{c}0.021 \\
09\end{array}$ & 5.67 & $\begin{array}{c}.367 \\
8\end{array}$ & $\begin{array}{c}0.0214 \\
7\end{array}$ & 5.84 & $\begin{array}{c}0.39 \\
80\end{array}$ & $\begin{array}{c}2.49 \\
5\end{array}$ & 6.27 & $\begin{array}{c}0.37 \\
90\end{array}$ & $\begin{array}{c}0.026 \\
06\end{array}$ & 6.87 \\
\hline $\mathrm{HL}(\mathrm{cm})$ & $\begin{array}{c}0.32 \\
51\end{array}$ & $\begin{array}{c}0.013 \\
51\end{array}$ & 4.15 & $\begin{array}{c}.329 \\
5\end{array}$ & $\begin{array}{c}0.0164 \\
2\end{array}$ & 4.98 & $\begin{array}{c}0.34 \\
22\end{array}$ & $\begin{array}{c}2.00 \\
5\end{array}$ & 5.86 & $\begin{array}{c}0.33 \\
23\end{array}$ & $\begin{array}{c}0.018 \\
18\end{array}$ & 5.47 \\
\hline POL (cm) & $\begin{array}{c}0.09 \\
32\end{array}$ & $\begin{array}{c}0.021 \\
27\end{array}$ & 22.82 & $\begin{array}{c}.090 \\
8\end{array}$ & $\begin{array}{c}0.0135 \\
3\end{array}$ & 14.9 & $\begin{array}{c}0.09 \\
14\end{array}$ & $\begin{array}{c}0.89 \\
0\end{array}$ & 9.74 & $\begin{array}{c}0.09 \\
21\end{array}$ & $\begin{array}{c}0.015 \\
07\end{array}$ & 16.36 \\
\hline PPL (cm) & $\begin{array}{c}0.31 \\
30\end{array}$ & $\begin{array}{c}0.026 \\
76\end{array}$ & 8.55 & $\begin{array}{c}.320 \\
0\end{array}$ & $\begin{array}{c}0.0188 \\
4\end{array}$ & 5.89 & $\begin{array}{c}0.33 \\
84\end{array}$ & $\begin{array}{c}1.99 \\
1\end{array}$ & 5.88 & $\begin{array}{c}0.32 \\
39\end{array}$ & $\begin{array}{c}0.024 \\
51\end{array}$ & 7.57 \\
\hline PPLL (cm) & $\begin{array}{c}0.38 \\
36\end{array}$ & $\begin{array}{c}0.020 \\
57\end{array}$ & 5.36 & $\begin{array}{c}.392 \\
1\end{array}$ & $\begin{array}{c}0.0211 \\
2\end{array}$ & 5.39 & $\begin{array}{c}0.41 \\
43\end{array}$ & $\begin{array}{c}2.12 \\
8\end{array}$ & 5.14 & $\begin{array}{c}0.39 \\
66\end{array}$ & $\begin{array}{c}0.024 \\
34\end{array}$ & 6.14 \\
\hline PAL $(\mathrm{cm})$ & $\begin{array}{c}0.73 \\
80\end{array}$ & $\begin{array}{c}0.029 \\
98\end{array}$ & 4.06 & $\begin{array}{c}.755 \\
5\end{array}$ & $\begin{array}{c}0.0328 \\
3\end{array}$ & 4.34 & $\begin{array}{c}0.74 \\
52\end{array}$ & $\begin{array}{c}2.82 \\
0\end{array}$ & 3.78 & $\begin{array}{c}0.74 \\
57\end{array}$ & $\begin{array}{c}0.030 \\
89\end{array}$ & 4.14 \\
\hline $\mathrm{BD}(\mathrm{cm})$ & $\begin{array}{c}0.44 \\
08\end{array}$ & $\begin{array}{c}0.021 \\
26\end{array}$ & 4.82 & $\begin{array}{c}.442 \\
6\end{array}$ & $\begin{array}{c}0.0260 \\
5\end{array}$ & 5.89 & $\begin{array}{c}0.41 \\
31\end{array}$ & $\begin{array}{c}2.66 \\
0\end{array}$ & 6.44 & $\begin{array}{c}0.43 \\
21\end{array}$ & $\begin{array}{c}0.027 \\
84\end{array}$ & 6.44 \\
\hline $\mathrm{ED}(\mathrm{cm})$ & $\begin{array}{c}0.08 \\
04\end{array}$ & $\begin{array}{c}0.011 \\
62\end{array}$ & 14.45 & $\begin{array}{c}.079 \\
2\end{array}$ & $\begin{array}{c}0.0092 \\
0\end{array}$ & 11.61 & $\begin{array}{c}0.08 \\
53\end{array}$ & $\begin{array}{c}1.14 \\
6\end{array}$ & 13.43 & $\begin{array}{c}0.08 \\
16\end{array}$ & $\begin{array}{c}0.010 \\
81\end{array}$ & 13.23 \\
\hline $\mathrm{CH}(\mathrm{cm})$ & $\begin{array}{c}0.18 \\
13\end{array}$ & $\begin{array}{c}0.024 \\
60\end{array}$ & 13.57 & $\begin{array}{c}.180 \\
2\end{array}$ & $\begin{array}{c}0.0236 \\
6\end{array}$ & 13.13 & $\begin{array}{c}0.17 \\
60\end{array}$ & $\begin{array}{c}2.76 \\
8\end{array}$ & 15.73 & $\begin{array}{c}0.17 \\
90\end{array}$ & $\begin{array}{c}0.025 \\
22\end{array}$ & 14.09 \\
\hline W (g) & $\begin{array}{l}11.3 \\
258 \\
\end{array}$ & $\begin{array}{c}2.625 \\
20 \\
\end{array}$ & 23.18 & $\begin{array}{c}9.76 \\
22 \\
\end{array}$ & $\begin{array}{c}3.7215 \\
5 \\
\end{array}$ & 38.12 & $\begin{array}{c}6.42 \\
42 \\
\end{array}$ & $\begin{array}{l}159 . \\
126 \\
\end{array}$ & 24.77 & $\begin{array}{c}9.18 \\
84 \\
\end{array}$ & $\begin{array}{c}3.450 \\
93 \\
\end{array}$ & 37.56 \\
\hline
\end{tabular}

Among the morphometric characters, weight (W), TL, and PAL showed high values in all the populations. The age of fish was not considered in the analysis as there was a high similarity in total and standard length. Besides, the coefficient of variation of these variables 
was less than $4 \%$, which indicated that the age of the sampled fish was very similar.

According to Yakubu and Okunsebor (2011), the size of fish is more important than its age, mainly because several factors in taxonomy, ecology, and physiology are more size-dependent than age-dependent. In this study, there was no significant difference between morphometric variables between males and females in all the sampled populations, so the effect of sex was not considered further in the analysis.

In the same way as this result, sex demonstrated a negligible effect on morphometric variables (Turan et al., 2005). Because of the very high genetic correlation between the expressions of body traits in the two sexes, Nguyen et al. (2007) also concluded that there was no need to treat trait expressions in the two sexes as different traits.

The result also showed a very high value of the coefficient of variation (between 23\% and 38\%) of body weight among the fish samples of the three populations. The mean values of all the recorded phenotypic variables were checked if they vary significantly in each population (Table 2 ).

Table 2. Means* \pm S.D. of morphometric variables of three O. niloticus populations.

\begin{tabular}{llll}
\hline Variables & Koka Reservoir & Lake Ziway & Lake Langano \\
\hline TL & $1.3137^{\mathrm{a}} \pm 0.02885$ & $1.3267^{\mathrm{b}} \pm 0.05862$ & $1.3656^{\mathrm{c}} \pm 0.03660$ \\
PDL & $0.3718^{\mathrm{a}} \pm 0.02074$ & $0.3674^{\mathrm{a}} \pm 0.02134$ & $0.3980^{\mathrm{b}} \pm 0.02483$ \\
HL & $0.3253^{\mathrm{a}} \pm 0.01321$ & $0.3293^{\mathrm{a}} \pm 0.01628$ & $0.3426^{\mathrm{b}} \pm 0.01983$ \\
POL & $0.0937^{\mathrm{a}} \pm 0.02096$ & $0.0912^{\mathrm{a}} \pm 0.01279$ & $0.0912^{\mathrm{a}} \pm 0.00857$ \\
PPCL & $0.3133^{\mathrm{a}} \pm 0.02691$ & $0.3201^{\mathrm{b}} \pm 0.01863$ & $0.3385^{\mathrm{c}} \pm 0.01984$ \\
PPLL & $0.3836^{\mathrm{a}} \pm 0.02001$ & $0.3921^{\mathrm{b}} \pm 0.02108$ & $0.4143^{\mathrm{c}} \pm 0.02089$ \\
PAL & $0.7380^{\mathrm{a}} \pm 0.02973$ & $0.7554^{\mathrm{b}} \pm 0.03288$ & $0.7438^{\mathrm{a}} \pm 0.02746$ \\
BD & $0.4401^{\mathrm{a}} \pm 0.02102$ & $0.4428^{\mathrm{a}} \pm 0.02601$ & $0.4132^{\mathrm{c}} \pm 0.02619$ \\
ED & $0.0805^{\mathrm{a}} \pm 0.01116$ & $0.0792^{\mathrm{a}} \pm 0.00861$ & $0.0852^{\mathrm{c}} \pm 0.01154$ \\
CH & $0.1807^{\mathrm{a}} \pm 0.02432$ & $0.1805^{\mathrm{a}} \pm 0.02323$ & $0.1757^{\mathrm{a}} \pm 0.02781$ \\
W & $11.3252^{\mathrm{a}} \pm 2.62533$ & $9.7617^{\mathrm{b}} \pm 3.72141$ & $6.4243^{\mathrm{c}} \pm 1.59111$ \\
\hline
\end{tabular}

Note: Means in the same row followed by different letters are significantly different $(\mathrm{P}<0.05)$.

The same result showing the impact of environmental variations on the morphometric and meristic differences of fish was reported by other authors (Akinrotimi et al., 2018: Alkinson and Sibly, 1997: Eyo, 2003: Fagbuaro, 2015: González et al., 2016: Jin et al., 2007: Kara et al., 2011: Liao et al., 2006: Scheiner, 1993). A very high morphological plasticity in fish can be caused by environmental conditions such as food abundance and temperature (Beacham, 1990: Eyo, 2003: Scheiner, 1993). According to Ezeafulukwe et al. (2015), morphological plasticity due to environmental variability is commonly found among many fish species, predominantly in freshwater fish species.

After data standardization according to Elliott and Hurley (1995), body weight (W) showed a very high value of the coefficient of variation (between $23 \%$ and
$38 \%)$. There was a significant $(p<0.05)$ difference in weight among the fish samples collected from the three water bodies. Samples from Lake Koka displayed a higher mean value $(11.3258 \pm 2.62520$ $\mathrm{gm})$. The ratio of POL/SL also showed a high value $(22 \%)$ of coefficients of variation. Moreover, ratios of ED/SL and $\mathrm{CH} / \mathrm{SL}$ showed roughly a coefficient of variation between 10 and 15\%. All other morphometric characters showed a coefficient of variation lower than $10 \%$.

All the coefficients of variation of different morphometric characters were significantly $(\mathrm{P}<0.05)$ different between populations. The mean W/SL ratio was 9.19. The mean ratios of $\mathrm{TL} / \mathrm{SL}$ and $\mathrm{PAL} / \mathrm{SL}$ represented 1.33 and 0.74 , respectively. The ratios of TL/SL, PDL/SL, $\mathrm{HL} / \mathrm{SL}, \mathrm{PPCL} / \mathrm{SL}, \mathrm{PPLL} / \mathrm{SL}, \mathrm{PAL} / \mathrm{SL}$, and $\mathrm{BD} / \mathrm{SL}$ showed a coefficient of variation lower than 10\%; ratios POL/SL, ED/SL, 
and CH/SL showed a coefficient of variation between 10 and $20 \%$, while the ratio of W/SL showed a coefficient of variation greater than $20 \%$.

Among populations, the W/SL and $\mathrm{POL} / \mathrm{SL}$ in Koka reservoir and PAL/SL and $\mathrm{BD} / \mathrm{SL}$ in Lake Ziway were significantly $(\mathrm{P}<0.05)$ higher. The ratios $\mathrm{TL} / \mathrm{SL}$, PDL/SL, HL/SL, PPCL/SL, PPLL/SL, and $\mathrm{ED} / \mathrm{SL}$ were significantly $(\mathrm{P}<0.05)$ higher in the Lake Langano population. Based on these relationships, fish from Lake Langano were significantly $(\mathrm{P}<0.05)$ more profound at the cranial level than Lakes Koka and Ziway populations that are profound at the caudal level, which is in line with the work of Turan et al. (2006) who reported that differences between populations of Tilapiine species were reflected mostly in head measurement.

In the same manner, a significant variation in the eye diameter, dorsal fin ray, caudal peduncle depth, and left gill raker of Sarotherodon galileaus from three man-made lakes (Oyewunmi et al., 2014), body depth and caudal peduncle length as the discriminating characters in Sarotherodon melanotheron from three different Creeks in River State (Akinrotimi et al., 2018) and the head length, body depth, and caudal peduncle width are reported by Ezeafulukwe et al. (2015) to be discriminating characters between Coptodon zilli from the wild and that of the ponds. The head length, total length, body weight, standard length, and pre-pelvic distance as the discriminating characters in Coptodon zilli from three major dams in Southwestern Nigeria was reported by Fagbuaro (2015).

Morphometric measurements can be used for species identification, hence a univariate analysis of twelve measurements expressed as percentages of the standard length of fish was performed. Most of the morphometric mean values of $O$. niloticus from the three populations were significantly $(\mathrm{P}<0.05)$ different from each other. Fish from Lake Koka was heavier (weight) than those coming from both Ziway and Langano lakes, and the difference is significant $(\mathrm{P}<0.05)$. Furthermore, TL, PPCL, and PPLL were also significantly $(\mathrm{P}<0.05)$ different in each population. Besides, the Langano population is significantly $(\mathrm{P}<0.05)$ different on $\mathrm{PDL}, \mathrm{HL}, \mathrm{BD}$, and ED from the other two populations.

The fish samples collected from Lake Ziway are significantly $(\mathrm{P}<0.05)$ different from Koka and Langano only in PAL. However, there is no significant difference in POL and $\mathrm{CH}$ between the three populations. This result is in line with the research results of Samaradivankara et al., (2012) who delineated Tilapia samples from Reservoirs in Sri Lanka into four groups using morphological methods.

\section{Length-Weight Relationship}

The length-weight relationship of the collected fish samples was calculated based on the logarithmic transformation of the data. The parameter ' $\mathrm{b}$ ' of the fish studied ranged from a minimum of 3.07to a maximum of 3.1686 , with a mean value of 3.11. The regression slope of all three populations was greater than 3 indicating that the fish had positive allometric growth. The length-weight relationship equations and their parameters were given in Table 3.

Table 3. Length-weight relationship equations and their parameters.

\begin{tabular}{lccc}
\hline \multicolumn{1}{c}{ Population } & Equation & 'b' & Coefficient of Determination $\left(\mathrm{r}^{2}\right)$ \\
\hline Koka & Log W=3.1686LogTL-2.0088 & 3.1686 & 0.9563 \\
Ziway & Log W=3.097LogTL-1.9161 & 3.097 & 0.8733 \\
Langano & Log W=3.0738LogTL-1.9507 & 3.0738 & 0.9643 \\
\hline
\end{tabular}

The length-weight relationship of the samples of $O$. niloticus was calculated based on the logarithmic transformation of the data. It provides important information concerning the structure and function of fish populations. In the current 
study, the length and weight relationship of $O$. niloticus were high $\left(\mathrm{r}^{2}=0.9563, \mathrm{r}^{2}=\right.$ 0.8733 , and $r^{2}=0.9643$ at Lakes Koka, Ziway, and Langano, respectively. It was significant at the 0.01 level and indicated that the bodyweight of this species increases as the total length increase. The same high $r^{2}$ value was also reported for other fish species in different water bodies (Dalu et al., 2013; Ndiaye et al., 2015; Saha et al., 2019).

According to Kleanthidis et al. (1999), the concept of cube law hypothetically suggested that the value of ' $\mathrm{b}$ ' for an ideal fish needs to be 3.0, which represents an isometric growth. In this study, the value of regression coefficient ' $b$ ' of the fish samples from Lakes Koka, Ziway, and Langano was 3.1686, 3.097, and 3.0738 , respectively with no fish population exhibiting an isomeric $(b=3)$ relative growth, which doesn't maintain their specific body shape throughout their life. Fish undergoing positive allometric growth is an indication of the stoutness of the body with an increase in length. $O$. niloticus at all three lakes had a positive allometric growth pattern as the value of regression coefficient ' $b$ ' was greater than 3 for all.

Thus, the weight of the fish was higher as compared to the cube of its length. The estimated length-weight coefficient (b) value of $O$. niloticus in this study is within the range of ' $b$ ' values in tropical fishes $(b=2.5-3.5)$ (Pauly and Gayanilo, 1997) and almost the same as the ' $b$ ' value reported before for Lake Ziway $(b=3.11)$ (Tadesse, 1997), and Lake Koka $(b=3.0541)$. A 'b' value of 3.026 for $O$. niloticus, which is within the same range as this result, was also reported by Kosai et al. (2014). The variation in the value of ' $b$ ' happens due to season, habitat, gonad maturity, sex, diet, stomach fullness, health, preservation techniques, and annual differences in environmental conditions (Bagenal and Tesch, 1978: Froese, 2006).

\section{The Fulton's Condition Factor (K)}

The Fulton's condition factor expresses the degree of the wellbeing of fishes in their habitat. In this study, it was calculated to be $1.48,1.2$, and 0.66 for a fish population of Lake Koka, Lake Ziway, and Lake Langano, respectively.

Fulton's condition factor $(\mathrm{K})$ is defined as the wellbeing of fish and is strongly influenced by both biotic and abiotic environmental conditions. It can be used as an index to assess the status of the aquatic ecosystem in which fish lives (Nazeef and Abubakar, 2013). In the current study, Fulton's condition factor (K) of $O$. niloticus samples collected from Lakes Koka, Ziway, and Langano were $1.48,1.2$, and 0.66 , respectively.

The lake Langano population showed the least value of condition factor indicating the possible existence of continuous environmental pressure, and/or less presence of phytoplankton and zooplankton, which are the most important food in the fish diet in the lake.

A condition factor of the same fish species in Lake Langano was reported as 1.67 (Tadesse, 1999). The relatively high condition factor in Lakes Koka and Ziway might be caused by the environmental differences that exist between these water bodies and Lake Langano. Fulton's condition factor for the same species in different water bodies in Ethiopia was reported: Lake Abaya, 1.43 (Berhan, 2016), Lake Hayq, 1.81 (Tessema et al. 2019), Lake Tana, 2.29 (Tadesse, 1999), Lake Chamo, 2.23 (Teferi and Admassu, 2002). A higher value of condition factor is correlated with high energy content, adequate food availability (high phytoplankton and zooplankton), reproductive potential, and favorable environmental conditions (Paukert and Rogers, 2004).

\section{Relationships}

Between Morphometric Variables

The correlation coefficients between transformed morphometric traits and standard length were calculated for all 
individuals in the three populations (Table 4) to check if the data transformation was effective in removing the effect of size. The pairwise comparisons revealed significant positive as well as negative correlations between the morphometric variables.

Table 4. Correlations between morphometric variables of $O$. niloticus.

\begin{tabular}{|c|c|c|c|c|c|c|c|c|c|c|c|}
\hline & $\mathrm{TL}$ & PDL & $\mathrm{HL}$ & POL & PPCL & PPLL & PAL & $\mathrm{BD}$ & ED & $\mathrm{CH}$ & $\mathrm{W}$ \\
\hline TL & 1 & & & & & & & & & & \\
\hline \multirow[t]{2}{*}{ PDL } & $0.408^{* * *}$ & 1 & & & & & & & & & \\
\hline & 0.000 & & & & & & & & & & \\
\hline \multirow[t]{2}{*}{ HL } & $0.399^{* * *}$ & $0.618^{* * *}$ & 1 & & & & & & & & \\
\hline & 0.000 & 0.000 & & & & & & & & & \\
\hline \multirow[t]{2}{*}{ POL } & 0.021 & $0.147^{* * *}$ & $0.241^{* * *}$ & 1 & & & & & & & \\
\hline & 0.680 & 0.004 & 0.000 & & & & & & & & \\
\hline \multirow[t]{2}{*}{ PPCL } & $0.367^{* *}$ & $0.395^{* * *}$ & $0.507^{* * *}$ & $0.164^{* * *}$ & 1 & & & & & & \\
\hline & 0.000 & 0.000 & 0.000 & 0.001 & & & & & & & \\
\hline \multirow[t]{2}{*}{ PPLL } & $0.439^{* * *}$ & $0.367^{* * *}$ & $0.380^{* * *}$ & 0.044 & $0.556^{* * *}$ & 1 & & & & & \\
\hline & 0.000 & 0.000 & 0.000 & 0.383 & 0.000 & & & & & & \\
\hline \multirow[t]{2}{*}{ PAL } & $0.316^{* *}$ & 0.066 & $0.187^{* * *}$ & -0.018 & $0.231^{* * *}$ & $0.319^{* * *}$ & 1 & & & & \\
\hline & 0.000 & 0.194 & 0.000 & 0.726 & 0.000 & 0.000 & & & & & \\
\hline \multirow[t]{2}{*}{$\mathrm{BD}$} & 0.068 & $-0.101^{*}$ & $-0.122^{*}$ & $0.115^{*}$ & -0.099 & $-0.135^{* *}$ & $0.211^{* *}$ & 1 & & & \\
\hline & 0.179 & 0.047 & 0.016 & 0.023 & 0.050 & 0.007 & 0.000 & & & & \\
\hline \multirow[t]{2}{*}{ ED } & $0.326^{\text {*** }}$ & $0.452^{* * *}$ & $0.530^{* * *}$ & $0.132^{* * *}$ & $0.287^{* * *}$ & $0.158^{* * *}$ & $0.110^{*}$ & -0.048 & 1 & & \\
\hline & 0.000 & 0.000 & 0.000 & 0.009 & 0.000 & 0.002 & 0.029 & 0.341 & & & \\
\hline \multirow[t]{2}{*}{$\mathrm{CH}$} & 0.037 & 0.071 & 0.083 & $0.119^{*}$ & 0.009 & -0.064 & 0.010 & $0.169^{* * *}$ & 0.094 & 1 & \\
\hline & 0.467 & 0.164 & 0.100 & 0.019 & 0.864 & 0.206 & 0.848 & 0.001 & 0.064 & & \\
\hline \multirow[t]{3}{*}{ W } & - & - & - & 0.021 & $-0.418^{* * *}$ & $-0.417^{* * *}$ & $-0.153^{* * *}$ & $0.269^{* * *}$ & $-0.450^{* * *}$ & $0.119^{*}$ & 1 \\
\hline & $0.451^{* *}$ & $0.395^{* * *}$ & $0.390^{* * *}$ & & & & & & & & \\
\hline & 0.000 & 0.000 & 0.000 & 0.674 & 0.000 & 0.000 & 0.002 & 0.000 & 0.000 & 0.019 & \\
\hline
\end{tabular}

**. Correlation is significant at the 0.01 level (2-tailed).

*. Correlation is significant at the 0.05 level (2-tailed).

\section{Discriminant Function Analysis}

In this study, seven characters were selected by stepwise DFA on morphometric data from three $O$. niloticus stocks. The characters selected on fish were total length (TL), pre-dorsal length
(PDL), pre-pelvic length (PPLL), pre-anal length (PAL), body depth (BD), eye diameter (ED), and weight (W). The analysis of the morphometric variables produced two significant discriminant functions (Table 5).

Table 5. Standardized canonical discriminant function coefficients for morphometric traits (Log transformed) of three Nile Tilapia populations.

\begin{tabular}{lcc}
\hline \multirow{2}{*}{ Traits } & \multicolumn{2}{c}{ Functions } \\
\cline { 2 - 3 } & \multicolumn{1}{c}{1} & 2 \\
\hline TL & -1.182 & 1.096 \\
PDL & -.833 & 1.227 \\
PPLL & -1.046 & .172 \\
PAL & 1.014 & -1.273 \\
BD & 1.370 & -.215 \\
ED & .232 & .578 \\
W & 1.083 & -.760 \\
Eigenvalue & $1.765^{\mathrm{a}}$ & $.186^{\mathrm{a}}$ \\
\% of variance & 90.5 & 9.5 \\
Cumulative \% & 90.5 & 100 \\
\hline
\end{tabular}

a. First 2 canonical discriminant functions were used in the analysis. 
The first function accounted for $90.5 \%$ of the variance and the second function $9.5 \%$ in the data. The larger the Eigenvalue, the more of the variance in the dependent variable is explained by that function. The bivariate plot of the two canonical functions separated the Lake Langano population (a negative sector) from the Lakes Koka and Ziway populations (a positive sector) (Figure 3).

The canonical discriminant function 1 and canonical discriminant function 2 were plotted to allow visual examination of the distribution of each sample along the $\mathrm{CF}$ axis that showed a clear betweensample differentiation (Figure 3). In the discriminant space, the Lake Langano samples were mostly isolated from all other samples. According to the canonical discriminant function coefficients obtained for morphometric data, the most influential variables for function 1 were PAL, BD, ED, and W.

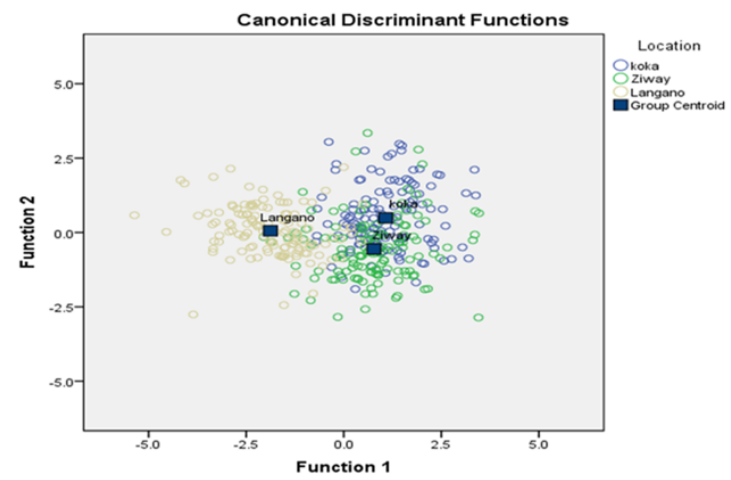

Figure 3. Scatter plot of the two canonical discriminant functions from analysis of morphometric traits for Nile Tilapia stocks.

The overall random assignment of individuals into their original group was high (72.9\%) (Table 6). The proportion of individuals correctly classified into their original group, i.e., Lake Langano, Lake Koka, and Lake Ziway was $88.4 \%, 66.4 \%$, and $66.2 \%$, respectively.

Table 6. Direct and percentage of grouped cases correctly classified into their original population.

\begin{tabular}{ccccccc}
\hline \multicolumn{6}{c}{ Classification Results } \\
\hline \multirow{6}{*}{ Original } & Count & Kocation & \multicolumn{2}{c}{ Predicted Group Membership } & \multirow{2}{*}{ Total } \\
\cline { 3 - 5 } & & Koka & Ziway & Langano & \\
\cline { 3 - 5 } & & Ziway & 33 & 43 & 4 & 132 \\
& & Langano & 3 & 12 & 11 & 130 \\
\cline { 2 - 5 } & $\%$ & Koka & 64.4 & 32.6 & 3.0 & 129 \\
\hline & Ziway & 25.4 & 66.2 & 8.5 & 100.0 \\
& & Langano & 2.3 & 9.3 & 88.4 & 100.0 \\
\hline
\end{tabular}

a. $72.9 \%$ of original grouped cases correctly classified.

The pairwise comparisons of transformed morphometric traits and standard length revealed significant positive as well as negative correlations. The result showed that the size effect was almost eliminated in the populations during analysis for instance expressed by the negative correlation of weight and the total length, which shows the impact of size on the morphometric variables are perfectly minimized by dividing all the variables by standard length. The morphometric relationships among different body parts of the fish can be used to determine possible differences between 
separated populations of the same species (Austin et al., 2008).

The Langano fish morphological measurements have highly deviated from the samples from the other two lakes. This high deviation might be related to the difference in the water chemistry, zooplankton and phytoplankton composition, diversity, etc., of Lake Langano from the other two that affected the fish morphometry. This is in line with what Turan et al. (2006) reported whereby habitat influenced the morphology of fish. According to Kara et al. (2011), morphological differentiation between fish populations in different localities/ habitats may not be related to genetic differentiation alone but by the inclusion of the environmental factors or their interactions. Hutchings (2004) demonstrated that phenotypic plasticity arises when the same genotype produces different phenotypes in different environments.

Morphological differentiation patterns among populations can indicate how diverse a population is. The Discriminant Function Analyses indicated that morphometric differentiation between the three samples was mainly due to differences in TL, PDL, PPLL, and ED which were significantly $(\mathrm{P}<0.05)$ higher in the Lake Langano population, and PAL, $\mathrm{BD}$, and $\mathrm{W}$ that were higher in the populations of Lakes Koka and Ziway. These morphometric variations may reflect differential habitat use. The Lake Langano population showed significantly $(\mathrm{P}<0.05)$ higher head length which is in line with a report by Gatz (1979) where relative head length was reported to be related to prey size.

According to Matthews (1988), eye diameter may reflect differences in turbidity. Moore (1950) described increases in cutaneous sense organs to compensate for reduced eye diameter in cyprinids adapted to turbid streams in North America. The eye diameter, which is significantly $(\mathrm{P}<0.05)$ higher for the Lake Langano population was may be related to the relatively less turbid Lake Langano,
Secchi depth $28.5 \mathrm{~cm}$ (Tadesse, 1999) as compared to for instance Lake Ziway, where turbidity is increasing noting Secchi depth as shallow as 17 to $20 \mathrm{~cm}$ (Lemma and Desta, 2016: Abera et al., 2018).

Geographical locations determine the type of abiotic components capable of modifying the fish morphology. For instance, elevation difference was reported to be correlated with body sizes (Alkinson and Sibly, 1997: Jin et al., 2007) and head sizes (Liao et al., 2006). Though it is not so big, there is an altitude variation among the three lakes (see study areas).

\section{CONCLUSION}

This study delineated $O$. niloticus samples from three rift valley lakes in Ethiopia based on morphometric measurements. The result revealed that the samples from Lake Langano were significantly different from samples of the other two lakes. Biotic and abiotic factors, genetics, and their interactions are believed to be the main cause of the observed morphometric variations.

\section{ACKNOWLEDGMENT}

This research was sponsored by the Ethiopian Biodiversity Institute. The authors would like to thank Mr. Getachew Senbete, Director of the Batu Fish and Other Aquatic Life Research Center, for allowing our research team to use their laboratory facilities. We also would like to acknowledge Mr. Kemal Ketebo for his assistance during the measurement of morphological variables. Mr. Tadesse Hunduma, who mapped the study area with ArcGIS software deserves appreciation.

\section{REFERENCES}

Abera, L., Getahun, A. and Lemma, B., 2018. Changes in fish diversity and fisheries in Ziway-Shala basin: The case of Lake Ziway, Ethiopia. International Journal of Advanced Research in Biological Sciences, 5(2), 
pp.165-177. http://dx.doi.org/10.2 2192/ijarbs.2018.05.02.017

Akinrotimi, O.A., Ukwe, O.I.K. and Amadioha, F., 2018. Morphometric characters and meristic counts of black chin tilapia (Sarotherodon melanotheron) from Buguma, Ogbakiri, and Elechi Creeks, Rivers State, Nigeria. International Journal of Poultry and Fisheries Sciences, 2(1), pp.1-8. http://dx.doi.org/10.1 5226/2578-1898/2/1/00106

Alkinson, D. and Sibly, R.M., 1997. Why are organisms usually bigger in colder environments? Making sense of the life-history puzzle. Trends in Ecology \& Evolution, 12(6), pp.235239. https://doi.org/10.1016/S016 9-5347(97)01058-6

Anderson, R.O., 1996. Length, weight, and associated structural indices. In: Nielsen LA, Johnson DL. (Eds.). Fisheries techniques. Bethesda, American Fish Society, pp.447-482.

Austin, E., Lucey, S., Stormer, D. and Juanes, F., 2008. Michael King: Review of "Fisheries Biology, Assessment and Management. Reviews in Fish. Biology and Fisheries, 18(4), pp.451-452. http://dx.doi.or $\mathrm{g} / 10.1007 / \mathrm{s} 11160-008-9090-1$

Awulachew, S.B., Yilma, A.D., Loulseged, M., Loiskandl, W., Ayana, M. and Alamirew, T., 2007. Water resources and irrigation development in Ethiopia (Vol. 123). Iwmi, p.78.

Bagenal, T.B. and Tesch, F.W., 1978. Age and growth (In: Methods for Assessment of Fish Production in Fresh Waters. Ed. T. Bagenal)Blackwell Scientific Publications. pp.101-136.

Beacham, T.D., 1990. A genetic analysis of meristic and morphometric variation in Chum Salmon (Onchorhynchus keta) at three different temperatures. Canadian Journal of Zoolgy, 68, pp.225-229. http://dx.doi.org/10.1139/z90-033

Berhan, K., 2016. The diversity, relative abundance, and some aspects of the biology of fish species in Lake Abaya,
Ethiopia, MSc. Thesis, Addis Ababa University.

Dalu, T., Clegg, B. and Nhiwatiwa, T., 2013. Length-weight relationships and condition factors of six fish species caught using gill nets in a tropical African reservoir, Zimbabwe. Transactions of the Royal Society of South Africa, 68(1), pp.7579. https://doi.org/10.1080/00359 19X.2012.733318

Elliott, J.M. and Hurley, M.A., 1995. The functional relationship between body size and growth rate in fish. Functional Ecology, 9(4), pp.625627. https://doi.org/10.2307/2390 153

Espinosa-Lemus, V., Arredondo-Figueroa, J.L. and Barriga-Sosa, I.D.L.A., 2009. Morphometric and genetic characterization of tilapia (Cichlidae: Tilapiini) stocks for effective fisheries management in two Mexican reservoirs. Hydrobiologica, 19(2), pp.95-107. http://www.scielo.org.mx/pdf/hbio /v19n2/v19n2a4.pdf

Eyo, J.E., 2003. Congeneric discrimination of morphometric characters among members of the pisces Genus: Clarias (Clariidae) in Anambra River, Nigeria. The Zoologist, 2(1), pp. 1-17. https://www.unn.edu.ng/ publications/files/11819

Ezeafulukwe, C.F., Njoku, D.C., Ekeledo, C.B. and Adaka, G.S., 2015. Morphomeristic characteristics of selected cichlid fishes from two aquatic environments in Imo State, Nigeria. International Journal of Veterinary Science, 4(3), pp.131135. http://www.ijvets.com/pdffiles/Volume-4-no-3-2015/131135.pdf

Fagbuaro, O., 2015. Morphometric Characteristics and Meristic Traits of Tilapia zillii From Three Major Dams of a Southwestern State, Nigeria. Continental Journal of Biological Sciences, 8(1), pp.1-7. https://doi.or g/10.5707/cjbiolsci.2015.8.1.1.7 
Froese, R., 2006. Cube law, condition factor, and weight-length relationships: History, metaanalysis, and recommendations. Journal of Applied Ichthyology, 22(4), pp.241-253. https://doi.org/ 10.1111/j.1439-0426.2006.00805.x

Gatz, A.J., 1979. Ecological morphology of freshwater stream fishes. Tulane Studies in Zoology and Botany, 21, 91e124.

Golubtsov, A.S. and Mina, M.V., 2003. Fish species diversity in the main drainage systems of Ethiopia: Current knowledge and research perspectives. Ethiopian Journal of Natural Resources, 5(2), pp.281-318. https://agris.fao.org/agris-search/s earch.do? recordID =ET2009000114

González, M.A., Rodriguez, J.M., Angón, E., Martínez, A., Garcia, A. and Peña, F., 2016. Characterization of morphological and meristic traits and their variations between two different populations (wild and cultured) of Cichlasoma festae, a species native to tropical Ecuadorian rivers. Archives Animal Breeding, 59(4), pp.435-444. https://doi.org/ 10.5194/aab-59-435-2016

Hasan, V., Mukti, A.T. and Putranto, T.W.C., 2019. Range expansion of the invasive nile tilapia Oreochromis niloticus (Perciformes: Cichlidae) in Java Sea and first record for Kangean Island, Madura, East Java, Indonesia. Ecology, Environment and Conservation, 25(July Suppl. Issue), pp.S187-S189. http://www.envirob iotechjournals.com/article_abstract. php?aid $=9708 \&$ iid $=276 \&$ jid $=3$

Hasan, V. and Tamam, M.B., 2019. First record of the invasive Nile Tilapia, Oreochromis niloticus (Linnaeus, 1758) (Perciformes, Cichlidae), on Bawean Island, Indonesia. Check List, 15(1), pp.225-227. https://doi. org/10.15560/15.1.225

Hassanien, H.A., Kamel, E.A., Salem, M.A. and Dorgham, A.S., 2011. Multivariate analysis of morphometric parameters in wild and cultured Nile tilapia Oreochromis niloticus. Journal of the Arabian Aquaculture Society, 6(2), pp.237-250. https://www.arabaqs.o rg/journal/vol_6/2/Text11-17.pdf

Hirut, Y., Mengistu, U., Goetsch, A.L. and Adugna, T., 2019. Quality of water from rift valley lakes of Ethiopia for livestock drinking. East African Journal of Veterinary and Animal Sciences, 3(1), pp.9-16. https://hara mayajournals.org/index.php/EAJV AS/article/view/897

Hockaday, S., Beddow, T.A., Stone, M., Hancock, P. and Ross, L.G., 2000. Using truss networks to estimate the biomass of Oreochromis niloticus, and to investigate shape characteristics. Journal of Fish Biology, 57(4), pp.981-1000. https:/ /doi.org/10.1111/j.1095-8649.200 0.tb02206.x

Hutchings, J.A., 2004. Norms of reaction and phenotypic plasticity in salmonid life histories. In: Hendry AP; Stearns SC, eds. Evolution illuminated; salmon and their relatives. Oxford University Press, New York, pp.154174.

Janko, A.M., 2015. Fish production, consumption, and management in Ethiopia. Nordic View to Sustainable Rural Development, p.310. https://11 ufb.llu.lv/conference/NJF/NJF_201 5 Proceedings Latvia.pdf

Jin, Y., Liu, N. and Li, J., 2007. Elevational variation in body size of Phryrocephalus vlangalii in the North Qinghai-Xizang (Tibetan) Plateau. Belgian Journal of Zoology, 137(2), pp.197-202. http://biblio.naturalsci ences.be/associated_publications/bj z/137-2/volume-137-2-pp-197-202. pdf

Kara, C., Alp, A. and Gürlek, M.E., 2011. Morphological variations of the trouts (Salmo trutta and Salmo platycephalus) in the rivers of Ceyhan, Seyhan, and Euphrates, Turkey. Turkish Journal of Fisheries and Aquatic Sciences, 11, pp.77-85. 
http://dx.doi.org/10.4194/trjfas.20 11.0111

Kleanthidis, P.K., Sinis, A.I. and Stergiou, K.I., $\quad 1999 . \quad$ Length-weight relationships for freshwater fishes in Greece. Naga, 22(4), pp.37-40. http://hdl.handle.net/1834/25895

Kosai, P., Sathavorasmith, P., Jiraungkoorskul, K. and Jiraungkoorskul, W., 2014. Morphometric characters of Nile tilapia (Oreochromis niloticus) in Thailand. Walailak Journal of Science and Technology (WJST), 11(10), pp.857-863. http://dx.doi.o rg/10.14456/WJST.2014.76

Lemma, B. and Desta, H., 2016. Review of the natural conditions and anthropogenic threats to the Ethiopian rift valley rivers and lakes. Lakes and Reservoirs: Science, Research and Management, 21(2), pp.133-151. http://dx.doi.org/10.1 111/lre.12126

LFDP (Lakes Fisheries Development Program), 1997. Lake management plans: Phase II, Working Paper 23. Ministry of Agriculture. pp.23.

Liao, J., Zhang, Z. and Liu, N., 2006. Altitudinal variation of skull size in Daurian pika (Ochotona daurica Pallas, 1868). Acta Zoologica Academiae Scientiarum Hungaricae, 52(3), pp.319-329. http://publicati on.nhmus.hu/actazool/cikkreszlete s.php?idhoz $=3750$

Matthews, W.J., 1988. Morphology, habitat use, and life history. In Patterns in Freshwater Fish Ecology, Chapman \& Hall, New York, p.756.

Mengesha, T.A., 2015. Fish species diversity in major river basins of Ethiopia: A review. World Journal of Fish and Marine Sciences, 7(5), pp.365-374. DOI: 10.5829/idosi.wjf ms.2015.7.5.95195

Merga, L.B., Mengistie, A.A., Faber, J.H. and Van den Brink, P.J., 2020. Trends in chemical pollution and ecological status of Lake Ziway, Ethiopia: a review focussing on nutrients, metals and pesticides.
African Journal of Aquatic Science, 45(4), pp.386-400. https://doi.org/ 10.2989/16085914.2020.1735987

Mert, R. and Cicek, E., 2010. Range expansion of introduced tilapia species (Oreochromis niloticus, L. 1758, Cichlidae) in Turkey. Journal of Animal and Veterinary Advances, 9(12), pp.1753-1756. http://dx.doi. org/10.3923/javaa.2010.1753.175 6

Mesfin, M., 2009. Heavy metal pollution in the rift valley Lakes of Hawassa and Koka, Ethiopia. MSc thesis, Bremen University of Aquatic Tropical Ecology, Bremen. p. 78

Moore, G.A., 1950. The cutaneous sense organs of barbeled minnows adapted to life in the waters of the Great Plains region. Transactions of the American Microscopical Society, 69(1), pp:69-95. https://doi.org/10 $.2307 / 3223350$

Naeem, M., Zuberi, A., Salam, A., Ali, M., Riaz-ul-Haq, M., Khalid, M., Mehreen, M., Nasir, M.F., Rasool, S.A. and Ishtiaq, A., 2011. Some morphometric relationships of hatchery reared male population of Oreochromis mossambicus from Pakistan. African Journal of Biotechnology, 10(75), pp.1736217366. https://doi.org/10.5897/AJ B11.1846

Naeem, M. and Salam, A., 2005. Morphometric study of freshwater bighead Carp Aristichthys nobilis from Pakistan in relation to the body size. Pakistan Journal of Biological Sciences, 8(5), pp.759-762. https:// dx.doi.org/10.3923/pjbs.2005.759. 762

Nazeef, S. and Abukakar, U.M., 2013. Diversity and condition factor of Fish species of Dadin Kowa Dam, Gombe State, Nigeria. Greener Journal of Biological Sciences, 3(10), pp.350-356. http://dx.doi.org/10.1 5580/GJBS.2013.10.102313920

Nazrul, K.M.S., Mamun, A.A., Sarker, B.S. and Tonny, U.S., 2011. Morphological variability of the $11^{\text {th }}$ 
generation strain of Nile tilapia, (Oreochromis niloticus) and traditional genetically improved farmed tilapia. Journal of the Bangladesh Agricultural University, 9(2), pp.345-349. http://dx.doi.org /10.3329/jbau.v9i2.11050

Ndiaye, W., Diouf, K., Samba, O., Ndiaye, P. and Panfili, J., 2015. The lengthweight relationship and condition factor of white grouper (Epinephelus aeneus, Geoffrey Saint Hilaire, 1817) at the South-west coast of Senegal, West Africa. International Journal of Advanced Research, 3(3), pp.145-153. http://www.document ation.ird.fr/hor/fdi:010066572

Nguyen, N.H., Khaw, H.L., Ponzoni, R.W., Hamzah, A. and Kamaruzzaman, N., 2007. Can sexual dimorphism and body shape be altered in Nile tilapia (Oreochromis niloticus) by genetic means?. Aquaculture, 272, pp.S38S46. https://doi.org/10.1016/j.aqu aculture.2007.08.013

Oyewunmi, J., Omoniyi, I.T. and Agbon, A., 2014. Comparative morphometrics and meristics of populations of Sarotherodon galileaus in three man-made lakes. Proceedings of the 29th Annual Conference of Fisheries Society of Nigeria (FISON), pp.126-132.

Paukert, C. and Rogers, R.S., 2004. Factors affecting condition of Flanmelmout Suckers in Colorado River, Grand Canyon, Arizona. North American Journal of Fisheries Management, 24(2), pp.648-653. htt ps://doi.org/10.1577/M03-087.1

Pauly, D. and Gayanilo Jr, F.C., 1997. A Bee: An alternative approach to estimating the parameters of a length-weight relationship from length frequency samples and their bulk weights. NAGA ICLARM, Manila, Philippines, 22, pp.15-26.

Saha, N., Ullah, M.R., Islam, M.S. and Hossain, M.B., 2019. Morphometric relationships between length weight and length-length and condition factor of four small indigenous fishes from the Payra River, Southern Bangladesh. Archives of Agricultural and Environmental Science, 4(2), pp.230-234. http://dx .doi.org/10.26832/24566632.2019. 0402016

Samaradivakara, S.P., Hirimuthugoda, N.Y., Gunawardana, R.H.A.N.M., Illeperuma, R.J., Fernandopulle, N.D., De Silva, A.D.and Alexander, P.A.B.D., 2012. Morphological variation of four tilapia populations in selected reservoirs in Sri Lanka. Tropical Agricultural Research, 23(2), pp.105-116. https://tar.sljol. info/articles/10.4038/tar.v23i2.464 2/

Scheiner, S.M., 1993. Genetics and evolution phenotype plasticity. Annual Review of Ecological Systematics, 24, pp.35-68. https://d oi.org/10.1146/annurev.es.24.1101 93.000343

Tadesse, Z., 1997. Breeding season, fecundity, length-weight relationship and condition factor of Oreochromis niloticus L. (Pisces: Cichlidae) in Lake Tana, Ethiopia. SINET: Ethiopian Journal of Science, 20(1), pp.31-47. http://dx.doi.org/ 10.4314/sinet.v20i1.18090

Tadesse, Z., 1999. The nutritional status and digestibility of Oreochromis niloticus L. diet in Lake Langeno, Ethiopia. Hydrobiologia, 416, pp.97106. https://doi.org/10.1023/A:10 03807318933

Talling, J.F. and Talling, I.B., 1965. The chemical composition of African lake waters. Internationale Revue der Gesamten Hydrobiologie und Hydrographie, 50(3), pp.421-63. https://doi.org/10.1002/IROH.196 50500307

Teferi, Y. and Admassu, D., 2002. The length-weight relationship, body condition, and sex ratio of tilapia (Oreochromis niloticus) in Lake Chamo, Ethiopia. SINET: Ethioian. Journal of Science, 25(1), pp.19-26. https://doi.org/10.4314/sinet.v25i 1.18070 
Tesfaye, G. and Wolff, M., 2014. The state of inland fisheries in Ethiopia: a synopsis with updated estimates of potential yield. Ecohydrology and Hydrobioliology, 14(3), pp.200-219. https://doi.org/10.1016/j.ecohyd.2 014.05 .001

Tessema, A., Getahun, A., Mengistou, S., Fetahi, T. and Dejen, E., 2019. Length-weight relationship, condition factor and some reproductive aspects of Nile Tilapia (Oreochromis niloticus) in Lake Hayq, Ethiopia. International Journal Fisheries and Aquatic Studies, 7(5), pp.555-561. https://w ww.fisheriesjournal.com/archives/2 019/vol7issue5/PartG/7-5-54755.pdf

Turan, C., Oral, M., Öztürk, B. and Düzgünes, E., 2006. Morphometric and meristic variation between stocks of bluefish (Pomatomus saltatrix) in the Black, Marmara, Aegean, and northeastern Mediterranean Seas. Fisheries Research, 79(1-2), pp.139-147. https://doi.org/10.1016/j.fishres.2 006.01.015

Turan, C., Yalçin, S., Turan, F., Okur, E. and Akyurt, I., 2005. Morphometric comparisons of African catfish, Clarias gariepinus, populations in Turkey. Folia Zoologica, 54(1/2), pp.165-172. https://www.ivb.cz/fo lia-zoologica/vol-54-no-1-2/

Wood, R.B. and Talling, J.F., 1988. Chemical and algal relationships in a salinity series of Ethiopian inland waters. Hydrobiologia, 158, pp.2967. https://doi.org/10.1007/BF000 26266

Wootton, R.J., 1990. Ecology of teleost fishes. Chapman and Hall, New York, 404 pp.

Yakubu, A. and Okunsebor, S.A., 2011. Morphometric differentiation of two Nigerian fish species (Oreochromis niloticus and Lates niloticus) using principal components and discriminant analysis. International Journal of Morphology, 29(4), pp.1429-1434. https://pesquisa.bvs alud.org/portal/resource/pt/lil-627 027

Zhou, L., Dan, X., Li, Y., Li, X., Chen, X., Li, Y. and Gan, L., 2015. Effect of reducing $3.2 \%$ dietary protein level on the growth performance and immunity of Nile tilapia (Oreochromis niloticus) with supplementation of multi amino acids. Iranian Journal of Fisheries Sciences, 14(4), pp.997-1009. http:/ /jifro.ir/article-1-1242-fa.html 